\title{
Hemşirelik Öğrencilerinin Pediatri Kliniğine İlişkin Klinik Rahatlık ve Endişe Durumları
}

\section{Clinical Comfort and Worry Status of Nursing Students Related to Pediatrics Clinic}

\author{
Fadime Üstüner Top ${ }^{1}$ (D) Nurşen Kulakaç² \\ ${ }^{1}$ Giresun Üniversitesi, Sağlık Bilimleri Fakültesi, Hemșirelik Bölümü, Giresun, TÜRKIYE \\ ${ }^{2}$ Gümüşhane Üniversitesi, Sağlık Bilimleri Fakültesi, Hemşirelik Bölümü, Gümüşhane, TÜRKIYE \\ Geliş tarihi/ Date of receipt: 01/09/2020 \\ Kabul tarihi/ Date of acceptance: 21/11/2020 \\ (c) Ordu University Faculty of Health Sciences, Department of Nursing, Turkey, Published online: 31/12/2020
}

ÖZ

Amaç: $\mathrm{Bu}$ araştırma, pediatri hemşireliği dersini alan öğrencilerin klinik rahatlık ve endișe durumlarının saptanması amacıyla planland1.

Yöntem: Araştırma analitik tipte planlandı. Örneklemi bir üniversitenin Sağllk Bilimleri Fakültesi hemşirelik bölümünde pediatri hemşireliği dersine kayıttlı öğrenciler oluşturdu. Araşıtırmada veriler bireysel tanıtım formu ve Pediatri Hemşireliği Öğrencileri Klinik Rahatlık ve Endişe Değerlendirme Ölçeği ile toplandı. Araştırmada istatistiksel değerlendirme bilgisayar ortamında yapıldı. Sonuçlar $\% 95$ 'lik bir güven aralığında analiz edildi ve istatistiksel olarak anlamlılık için $\mathrm{p}<0.05$ referans alındı.

Bulgular: Öğrencilerin yaş ortalaması $21.47 \pm 1.18$ ve \%73'ü kadındır. Pediatri Hemşireliği Öğrencileri Klinik Rahatlık ve Endişe Değerlendirme Ölçeği Rahatlık alt boyut puanının 14.64 \pm 2.38 , Endișe alt boyutu puanının $11.72 \pm 2.69$ olduğu belirlendi. Hemşirelik mesleğini seven $(\mathrm{p}=0.008)$, bugün seçme şansı olsaydı yine hemşirelik mesleğini seçecek olan $(\mathrm{p}=0.044)$ ve hemşirelik mesleğini bırakmak istemeyen $(\mathrm{p}=0.005)$ öğrencilerin Rahatlık alt boyut puanlarının anlamlı olarak yüksek olduğu bulundu.

Sonuç: Bu çalıșma sonucunda hemșirelik öğrencilerinin pediatri kliniğine ilişkin klinik rahatlık ve klinik endișe durumlarının orta düzeyde olduğu belirlendi. Öğrencilerin mesleğini isteyerek seçme ve sevme durumları klinik rahatlığı etkilemektedir.

Anahtar kelimeler: Klinik eğitim, Klinik endişe, klinik rahatlık, pediatri hemşirelik

\begin{abstract}
Objective: This study was planned to determine the clinical comfort and anxiety states of the students taking Pediatrics Nursing course. Method: The sample of the study was analytical type composed of students taking Pediatrics Nursing course at the Faculty of Health Sciences of the nursing department of a university. The data in this study; collected with the individual introduction form and the Clinical Comfort and Anxiety Assessment Tool of Pediatric Nursing Students. The research was conducted in the statistical analysis computer.The results were analyzed within a confidence interval of $95 \%$ and $p<0.05$ was considered as statistically significant.

Results: The average age of students is $21.47 \pm 1.18$ and $73 \%$ of them are women. Pediatric Nursing Students Clinical Comfort and Anxiety Assessment Scale was determined that the Comfort subscale score was $14.64 \pm 2.38$, and the Worry subscale score was 11.72 \pm 2.69 . Comfort subscale scores of the students who love nursing profession $(p=0.008)$, who would choose the nursing profession if they had the chance to choose today $(\mathrm{p}=0.044)$ and who did not want to leave the nursing profession $(\mathrm{p}=0.005)$ were significantly higher.

Conclusion: In this study, it was observed that the pediatric clinic nursing students had a moderate level of clinical comfort and clinical worry. Students' willingness to choose and love their profession affects clinical comfort.
\end{abstract}

Keywords: Clinical education, clinical worry, clinical comfort, pediatric nursing

ORCID IDs of the authors: FÜT: 0000-0002-7341-5704, NK: 0000000254271063

Sorumlu yazar/Corresponding author: Doç. Dr. Fadime ÜSTÜNER TOP

Giresun Üniversitesi, Sağlık Bilimleri Fakültesi, Hemșirelik Bölümü, Giresun, TÜRKIYE

e-posta/e-mail: fadikom@hotmail.com

Atıf/Citation: Üstüner Top F, Kulakaç N. (2020). Hemşirelik öğrencilerinin pediatri kliniğine ilişkin klinik rahatlık ve endișe durumları. Ordu

Üniversitesi Hemşirelik Çalışmaları Dergisi, 3(3), 280-288. DOI: 10.38108/ouhcd.788788 


\section{Giriş}

Hemşirelik eğitimi, bilim ve sanat temelli, teorik bilgi ve klinik uygulamalı öğrenim ve öğretim yaşantılarının birbirini tamamlamasından oluşan planlı bir eğitim sistemidir. Hemşirelik eğitimi ile öğrenciye bilişsel, duyuşsal ve psikomotor boyutta temel bilgi, beceri ve tutumlar kazandırarak, teorik bilgi ile klinik uygulamayı birleştirebilen, eleştirel düşünebilen ve etkin problem çözme becerisi kazanmış hemşireler yetiştirmek amaçlanmaktadır (Karagözoğlu 2005; Facioneve ark., 2017; Muslu ve Özsoy, 2017).

Klinik uygulamalar, öğrencilerin uygulama becerilerini kazanmalarına ve geliştirmelerine firsatlar sağlayarak eğitim sürecinin önemli bir bölümünü oluşturmakta olup, teorik eğitimin bütünleyici bir parçasıdır (Egan ve Jaye, 2009; La Sala ve ark., 2019; Moghaddam ve ark., 2020). Klinik ortam deneyimleri; öğrencilerin öğrenmelerinin geliștirilmesi, profesyonel kültür ile davranış ve tutumlarının şekillenmesi ve güçlü beceriler geliştirmesine katkıda bulunur (Henderson ve ark., 2002). Klinik alan, öğrenci hemşirelerin profesyonel rollerine hazırlanmalarında yeri doldurulmaz şekilde önemlidir ve hemşirelik eğitimin merkezi olarak görülür (Chan 2002).

Geleneksel sinıf ortamlarının aksine, klinik eğitim karmaşık bir sosyal alanda gerçekleşir. $\mathrm{Bu}$ ortamda öğrencilerin tutumlarını, yeterliliklerini, kişilerarası iletişim becerilerini, eleştirel düşünme ve klinik problem çözme yeteneklerini geliştirmeleri sağlanır. Hemşire öğrencilerinin mesleki bilgi, beceri, yeterlilik ve profesyonel kimlikleri klinik eğitim ortamında şekillenmektedir. Diğer taraftan klinik ortamdaki birçok faktör etkin eğitimin sağlanmasında güçlük yaşanmasına neden olarak öğrenmeyi olumsuz etkileyebilmektedir (Chan 2002; Jimenez ve ark., 2010; Moghaddam ve ark., 2020). Hemşirelik öğrencilerine göre, klinik deneyimler, özellikle bu deneyimler pediatrik klinik ortamda çocukları içerdiğinde yüksek derecede stres ve endişe yaşamalarına nedeni olabilmektedir (Jimenez ve ark., 2010; Elçigil ve Yıldırım Sarı, 2011; Lassche ve ark., 2013; Aedh ve ark., 2015; La Sala ve ark., 2019). Pediatri hemşireliğine ilişkin pediatri klinik öğrenme ortamı, çocuğa ve ebeveynlere özgü bakıma ilişkin çok özel özelliklere sahiptir. Öğrencilerin, çocuk sağlığı ve hastalıkları hemşireliğinin simüle edilmiş bir ortamda eğitimleri yoluyla spesifik bilgi ve becerilerine sahip olmaları gerekmektedir (Theofanidis ve Fountouki, 2006). Pediatrinin hizmet alanı, çocuğun döllenme anından ergenliğin tamamlanması olarak kabul edilen 18 yaşa kadar devam eden geniş bir yelpazeyi oluşturmaktadır. Çocukların erişkinlerden farklı fiziksel, fizyolojik, davranışsal ve psikolojik özellikleri, büyüme ve gelişme sürecinin devamlılığı yaklaşımları şekillendirmektedir. Uygulamaları çocuklar üzerinde gerçekleştirmek zor olabilir çünkü büyüme ve gelişimdeki farklılıklardan dolayı işlemlerle ilgili açıklamaları anlamada zorlanabilirler, iletişim yetenekleri sinırlıdır ve uygulanan teknikler yetişkinlere uygulanandan biraz daha farklıdır (Randall ve ark., 2008; Cinar ve Altun, 2012; Silva ve ark., 2015). Ayrica klinik uygulama ortamında öğrenciler yanlış bir şeyler yapabilme, bakım verdiği bireylere zarar verebilme, olumsuz geribildirimler alabilme, yeterli mesleki bilgi ve becerinin olmaması gibi düşünceleri yoğun yaşayabilmekte ve öz güvenlerini kaybedebilmektedir (Jimenez ve ark., 2010; Chen, 2010; Aedh ve ark., 2015). Çocuğun gelişimsel evresine göre, hem çocukların hem de aile bireylerinin farklı ihtiyaçları vardır. Her gelişimsel evre farklı görüşme, muayene, bakım ve danışma yaklaşımları gerektirir.

Pediatrik klinik uygulama döneminde çocuk hastaların bakımında öğrencilerin öğrenme deneyimi kolay ve basit bir süreç değildir (Theofanidis ve Fountouki, 2006). Öğrencilerin pediatri klinik performanslarını uygulamaya ilişkin yaşadıkları stres ve endişe durumları etkilemekte olup, bu durum klinik becerilerin uygun şekillenmesini önlemekte ve başarısını tehdit etmektedir (Glasper ve ark., 2006; Elçigil ve Y1ldırım Sarı, 2011; Lassche ve ark., 2013; Arslan ve ark., 2018). Bu endişeleri hafifletmek pediatrik klinik ortamda daha iyi öğrenci sonuçlarına katkıda bulunabilir.

$\mathrm{Bu}$ araştırma, pediatri dersi alan hemşirelik öğrencilerinin klinik rahatlık ve endişe durumlarının belirlenmesi amacıyla planlanmıştır. Pediatri dersi alan hemşirelik öğrencilerin klinik rahatlık ve endişe durumlarının belirlenmesinin uygulama performansını artıracak eğitim ve girişimlerin geliştirilmesinde yol gösterici olacaktır.

$\mathrm{Bu}$ genel amaç doğrultusunda belirlenen araştırmanın soruları şu şekildedir:

- Katılımcıların bireysel özellikleri nedir?

- Pediatri Hemşireliği Öğrencilerinin Klinik Rahatlik ve Endişe düzeyi nedir?

- Pediatri Hemşireliği Öğrencilerinin Klinik Rahatlık ve Endişe Değerlendirme durumlarını etkileyen faktörler ne/nelerdir? 


\section{Yöntem}

Araştırma analitik tipte planlanmıştır. Araştırmanın evrenini, 2019-2020 Eğitim-Öğretim y1lı bahar döneminde Karadeniz Bölgesinin kuzeyinde yer alan bir il merkezinde bulunan üniversitenin hemşirelik bölümünde pediatri dersi alan öğrencileri oluşturmuştur. Evrene ulaşılabilirlik dikkate alınarak örneklem seçimine gidilmemiş, çalışmanın yapıldığ 1 kurumda, veri toplama tarihlerinde araştırmaya alınma kriterlerini taşıyan ve gönüllü olan öğrencilerin tamamı $(n=127)$ çalışmaya dahil edilmiştir. Pediatri klinik uygulamasına çıkmamış olmak, pediatri dersi alıyor olmak, katılmaya gönüllü olmak araştırmaya alınma kriterleridir. Pediatri dersini ikinci kez alan 2 ögrenci ile katılmayı kabul etmeyen 3 öğrenci örnekleme dahil edilmemiş ve örneklemin \%96'sına ulaşılarak çalışma 122 öğrenci ile tamamlanmıştır.

\section{Veri Toplama Araçları}

$\mathrm{Bu}$ araştırmada veri toplama aracı olarak; online olarak hazırlanmış form kullanılmıştır. Anket formu Google Forms web uygulamasıyla hazırlanarak öğrencilerin akıllı telefonlarına WhatsApp mesajlaşma programı aracılığıyla gönderilmiştir. Anket formu; Bireysel Tanitım Formu, Pediatri Hemşireliği Öğrencileri Klinik Rahatlık ve Endişe Değerlendirme Ölçeği'nden oluşmaktadır.

Bireysel Tanitim Formu: $\mathrm{Bu}$ form literatürden yararlanılarak araştırmacı tarafından hazırlanmıştır. Formda; öğrencilere ait sosyo demografik bilgiler (yaş, cinsiyet, kardeş sayısı, aile tipi, yaşadığı yer), mesleğe ilişkin bilgiler ve çocuk oyunlarını bilme, çocuk kitapları okuma şeklinde 20 soru yer almaktadır. Form uygulama öncesi pediatri alanında uzman beş öğretim üyesinin görüşüne sunulmuş olup, öneriler doğrultusunda son hali hazırlanmıştır.

Pediatri Hemşireliği Öğrencileri Klinik Rahatlk ve Endişe Değerlendirme Ölçeği (Pediatric Nursing Student Clinical Comfortand Worry Assessment Tool): Ölçek Al-Qaaydeh, Lassche Macintosh tarafından ilk kez pediatri kliniğine çıkan hemşirelik ögrencilerinin klinik ortamındaki rahatlık ve endișe durumlarını belirlemek amacıyla geliştirilmiştir (AlQaaydeh ve ark., 2012). Arslan ve arkadaşları tarafından 2018 yılında ölçeğin Türkçe geçerlilik ve güvenilirlik çalışması yapılmıştır. Ölçek toplam 11 sorudan oluşmakta olup, bunların 6'si öğrencilerin pediatri kliniği sırasındaki rahatlık seviyesini ve 5 'i ise endişe düzeyini belirlemekte kullanılmaktadır. $\mathrm{Bu}$ ölçüm aracı 4'lü likert tipi bir ölçektir. Ölçeğin seçenekleri "1-Kesinlikle katıliyorum", "2Kat1lyorum", "3-Kat1lmıyorum" ve "4-Kesinlikle katılmıyorum" ifadelerini içermektedir. Ölçeğin ters kodlanan soruları bulunmaktadır. Ölçeğin rahatlık alt boyutunun 3. ve 5. maddeleri ters maddeler olup, bu nedenle maddelerin puanlaması ters yapılmıștır. Cronbach alpha güvenirlik değeri alt boyutlardan Rahatlık Seviyesi için 0.68, Endişe için 0.89 bulunmuştur (Arslan ve ark., 2018). Bu çalışmada ise Cronbach alpha güvenirlik değeri alt boyutlardan Rahatlık boyutu için 0.63 , Endişe boyutu için 0.78 olarak tespit edilmiştir.

\section{Verilerin Toplanması}

Araştırma verileri araştırmacılar tarafından 1520 Haziran 2020 tarihinde; "Bireysel Tanitım Formu" ve pediatri kliniğine ilişkin "Pediatri Hemşireliği Öğrencileri Klinik Rahatlık ve Endişe Değerlendirme Ölçeği” kullanılarak toplanmıştır. Tüm dünyayı etkisi altına alan Covid-19 pandemisi nedeni ile Türkiye'de 2019-2020 Eğitim Öğretim yılı bahar döneminde gerçekleştirilen yüz yüze eğitim sürecine online eğitimlerle devam etmek durumunda kalınmıștır. Veriler online teorik eğitim süreci tamamlandıktan, klinik uygulama süreci başlamadan toplanmıştır. Online olarak düzenlenen anketin bağlantısı, seçilen lisans programında öğrenim gören bir öğrenciye araştırmacı tarafından internetten gönderilmiş ve sınıf arkadaşlarına iletmesi için teşvik edilmiştir. Anket formu başında katılımcılara araştırma konusu, amacı, yararları hakkında açıklama yapılmış olup, gönüllülük ilkesine özen gösterilerek yazılı onamları alınarak veri toplama aşaması sonlandırılabilmiştir. Ayrıca öğrenci-eğitici etkileşimi önlemek amacı formlarda isim belirtilmemiş ve formlar toplu olarak değerlendirilmiștir. Anket formunun doldurulma süresi ortalama 10 dakika sürmüştür.

\section{Verilerin Değerlendirilmesi}

Araştırmada istatistiksel değerlendirme için SPSS (Statistical Package for Social Sciences) 22.0 paket programı kullanıldı. Veri toplama bittiğinde verilerin normalliği Kolmogorow-Smirnov testi ile değerlendirildi. Tanımlayıcı istatistiklerde sayısal veriler ortalama \pm standart sapma (minimummaksimum) ile ifade edilmis ve kategorik veriler sayı ve yüzde olarak ifade edilmiştir. Sayısal değişkenler için parametrik test varsayımlanı sağlanamadığından, her iki grubu karşılaştırmak için Mann-Whitney U ve Kruskal Wallis analizi yapıld1. Sonuçlar \% 95'lik bir güven aralığında analiz edildi ve istatistiksel olarak anlamlılık için $\mathrm{p}<0.05$ referans alınd1.

\section{Bulgular}

Öğrencilerin yaş ortalaması $21.47 \pm 1.18$ (min: 20; max: 27) ve \%73'ü kadındır. Öğrencilerin 
\%88.5'inin düz lise mezunu, \%77.9'unun çekirdek aile yapısına sahip, \%50'sinin yaşadıkları en uzun merkezin il ve \%81.1'inin gelir düzeyinin orta seviyede olduğu bulundu. Öğrencilerin \%82'sinin hemşirelik mesleğini sevdiği, \%64.8'inin hemşirelik mesleğini kendi isteği ile seçtiği, \%52.5'inin bugün seçme imkanı olsa tekrar hemşirelik mesleğini seçeceğini ifade ettikleri belirlendi. Öğrencilerin \%82.8'inin çocuk oyunlarını bildiği, \%52.5'inin çocuk kitapları okumadığı, \%66.4'ünün çocuk haklarını bildiği, \%62.3'ünün çalışma hayatında pediatri kliniğinde çalışmak istemediği ve \%69.7'sinin akademik başarılarını 'orta düzeyde' algiladıkları saptandı.

Pediatri Hemşireliği Öğrencileri Klinik Rahatlık ve Endişe Değerlendirme Ölçeği Rahatlık alt boyutu puan1 $14.64 \pm 2.38$ (min: 8; max: 23 ) ve Endișe alt boyutu puan1 $11.72 \pm 2.69$ (min: 5; max: 19) olarak bulundu (Tablo 1). Öğrencilerin \%62.3'ünün pediatrik tanılama yaparken kriz ve keder durumlarında çocuklara ve ailelerine destek sağlama konusunda kendilerini rahat hissettikleri belirlendi. Ayrıca öğrencilerin 45.9'u bir çocuğa ilaç uygularken, \%42.6's1 ağrılı işlemler sırasında çocuklar ve ailelerin baş etmelerine yardımcı olma konusunda kendilerini rahat hissetmedikleri bulundu. Öğrencilerin \%61.5'inin klinik uygulama sürecinde bir çocukta ağrıya sebep olma konusunda ve \%54.9'unun bir çocuğa fiziksel olarak zarar verme konusunda endişeli oldukları saptandı (Tablo 2).

Tablo 1. Öğrencilerin Pediatri Hemşireliği Öğrencileri Klinik Rahatlık ve Endişe Değerlendirme Ölçeği Alt Boyutlarına İlişkin Puan Ortalamaları $(\mathrm{n}=122)$

\begin{tabular}{lcc}
\hline $\begin{array}{l}\text { Pediatri Hemşireliği } \\
\text { Öğrencileri Klinik }\end{array}$ & & \\
$\begin{array}{l}\text { Rahatlık ve Endişe } \\
\text { Değerlendirme }\end{array}$ & Ort. \pm SS. & $\begin{array}{c}\text { Median } \\
\text { (min.-max) }\end{array}$ \\
Ölçeği Alt Boyutları & & \\
\hline Rahatlık & $14.64 \pm 2.38$ & $15.0(8-23)$ \\
\hline Endişe & $11.72 \pm 2.69$ & $12.0(5-19)$ \\
\hline
\end{tabular}

Tablo 2. Pediatri Hemşireliği Öğrencileri Klinik Rahatlık ve Endişe Değerlendirme Ölçeğine Verilen Yanıtların Dağılımı $(\mathrm{n}=122)$

\begin{tabular}{|c|c|c|c|c|c|c|c|c|}
\hline \multirow[t]{2}{*}{ Pediatri Servisindeki Rahatlık Seviyesi } & \multicolumn{2}{|c|}{$\begin{array}{l}\text { Kesinlikle } \\
\text { Katılıyorum }\end{array}$} & \multicolumn{2}{|c|}{ Katılıyorum } & \multicolumn{2}{|c|}{$\begin{array}{l}\text { Katılmiyoru } \\
\mathbf{m}\end{array}$} & \multicolumn{2}{|c|}{$\begin{array}{c}\text { Kesinlikle } \\
\text { Katılmıyorum }\end{array}$} \\
\hline & $\mathbf{n}$ & $\%$ & $\mathbf{n}$ & $\%$ & n & & $\mathbf{n}$ & $\%$ \\
\hline Pediatrik tanılama yaparken rahatım & 5 & 4.1 & 76 & 62.3 & 39 & 32 & 2 & 1.6 \\
\hline 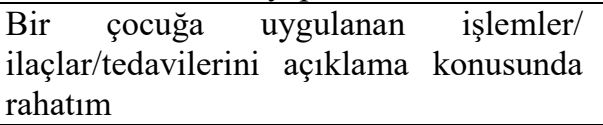 & 8 & 6.6 & 70 & 57.4 & 42 & 34.4 & 2 & 1.6 \\
\hline $\begin{array}{l}\text { Bir çocuğa ilaç uygularken kendimi rahat } \\
\text { hissetmiyorum. }\end{array}$ & 19 & 15.6 & 56 & 45.9 & 41 & 33.6 & 6 & 4.9 \\
\hline $\begin{array}{l}\text { Çocuğa yapılacak işlemleri ya da } \\
\text { terapileri uygulama konusunda rahatım }\end{array}$ & 5 & 4.1 & 66 & 54.1 & 44 & 36.1 & 7 & 5.7 \\
\hline $\begin{array}{l}\text { Ağrılı işlemler sırasında çocuklar ve } \\
\text { ailelerin baş etmelerine yardımcı olma } \\
\text { konusunda kendimi rahat hissetmiyorum }\end{array}$ & 16 & 13.1 & 52 & 42.6 & 49 & 40.2 & 5 & 4.1 \\
\hline $\begin{array}{l}\text { Kriz ve keder durumlarında çocuklara ve } \\
\text { ailelerine destek sağlama konusunda } \\
\text { rahatım }\end{array}$ & 10 & 8.2 & 76 & 62.3 & 35 & 28.7 & 1 & 0.8 \\
\hline \multicolumn{9}{|l|}{ Klinik Rotasyondaki Endişeler } \\
\hline $\begin{array}{l}\text { Hasta bir çocuğun bakımı konusunda } \\
\text { endişe duyuyorum. }\end{array}$ & 25 & 20.5 & 62 & 50.8 & 35 & 28.7 & - & - \\
\hline $\begin{array}{l}\text { Bu rotasyon sırasında bir çocuğa fiziksel } \\
\text { zarar verme konusunda endişeliyim }\end{array}$ & 17 & 13.9 & 67 & 54.9 & 33 & 27.0 & 5 & 4.1 \\
\hline $\begin{array}{l}\text { Bu rotasyon sirasında bir çocuğa } \\
\text { duygusal zarar verme konusunda } \\
\text { endişeliyim }\end{array}$ & 15 & 12.3 & 39 & 32.0 & 53 & 43.4 & 15 & 12.3 \\
\hline $\begin{array}{l}\text { Bu rotasyon sırasında bir çocukta ağrıya } \\
\text { sebep olma konusunda endişeliyim }\end{array}$ & 14 & 11.5 & 75 & 61.5 & 29 & 23.8 & 4 & 3.3 \\
\hline $\begin{array}{l}\text { Çocukların aileleri } \\
\text { konusunda endişeliyim }\end{array}$ & 6 & 4.9 & 37 & 30.3 & 68 & 55.7 & 11 & 9.0 \\
\hline
\end{tabular}


Hemşirelik mesleğini seven $(p=0.008)$, bugün seçme şansı olsaydı yine hemşirelik mesleğini seçecek olan $(p=0.044)$ ve hemşirelik mesleğini bırakmak istemeyen $(\mathrm{p}=0.005)$ öğrencilerin Rahatlık alt boyut puanının anlamlı olarak yüksek olduğu bulundu. Öğrencilerin cinsiyet, mezun olunan lise, en uzun yaşanılan yer, hemşirelik mesleğini isteyerek seçme, çocuk oyunlarını bilme, çocuk kitapları okuma, çocuk haklarını bilme ve mezuniyet sonrası çocuk servisinde çalışmayı isteme durumlarına göre Rahatlık ve Endişe alt boyutu puan ortalamaları arasinda istatistiksel olarak anlamlı farklılık belirlendi ( $\mathrm{p}>0.05)$ (Tablo $3)$.

Tablo 3. Öğrencilerin Bazı Tanımlayıcı Özelliklerine Göre Pediatri Hemşireliği Öğrencileri Klinik Rahatlık ve Endişe Değerlendirme Ölçeği Alt Boyutları Puanlarının Dağılımı (n=122)

\begin{tabular}{|c|c|c|c|c|}
\hline \multirow[t]{2}{*}{ Özellik } & & \multirow[b]{2}{*}{ n $(\%)$} & \multicolumn{2}{|c|}{$\begin{array}{l}\text { Pediatri Hemşireliği Öğrencileri Klinik } \\
\text { Rahatlık ve Endișe Değerlendirme Ölçeği }\end{array}$} \\
\hline & & & $\begin{array}{c}\text { Rahatlık } \\
\text { Medyan (25-75) } \\
\text { persentil }\end{array}$ & $\begin{array}{c}\text { Endişe } \\
\text { Medyan (25-75) } \\
\text { persentil }\end{array}$ \\
\hline \multirow[t]{2}{*}{ Cinsiyet } & Kadın & $89(73.0)$ & $15.00(13-16)$ & $12.00(14-10)$ \\
\hline & Erkek & $33(27.0)$ & $\begin{array}{c}14.00(12-16) \\
p=0.281\end{array}$ & $\begin{array}{c}12.00(10-13) \\
\mathrm{p}=0.682\end{array}$ \\
\hline \multirow[t]{2}{*}{ Mezun olunan lise } & $\begin{array}{l}\text { Sağlık } \\
\text { meslek lisesi }\end{array}$ & $14(11.5)$ & $14.50(12-15)$ & $13.00(11-14)$ \\
\hline & Düz lise & $108(88.5)$ & $\begin{array}{c}15.00(13-16) \\
\mathrm{p}=0.444\end{array}$ & $\begin{array}{c}12.00(10-13) \\
\mathrm{p}=0.117\end{array}$ \\
\hline \multirow[t]{3}{*}{ En uzun yaşanılan yer } & İl & $61(50.0)$ & $15.00(13-17)$ & $12.00(10-13)$ \\
\hline & İlçe & $42(34.4)$ & $15.00(13-16)$ & $11.00(10-14)$ \\
\hline & Köy & $19(15.6)$ & $\begin{array}{c}14.00(12-16) \\
\mathrm{p}=0.271\end{array}$ & $\begin{array}{c}11.00(10-14) \\
\mathrm{p}=0.446\end{array}$ \\
\hline \multirow[t]{2}{*}{ Hemşireliği sevme durumu } & Evet & $100(82.0)$ & $16.00(14-17)$ & $12.00(10-14)$ \\
\hline & Hayır & $22(18.0)$ & $\begin{array}{c}14.50(13-16) \\
\mathbf{p}=\mathbf{0 . 0 0 8} *\end{array}$ & $\begin{array}{c}11.00(9-12) \\
\mathrm{p}=0.076\end{array}$ \\
\hline \multirow{2}{*}{$\begin{array}{l}\text { Hemşireliği isteyerek seçme } \\
\text { durumu }\end{array}$} & Evet & $79(64.8)$ & $14.00(13-16)$ & $12.00(10-14)$ \\
\hline & Hayır & $43(35.2)$ & $\begin{array}{c}15.00(13-17) \\
\mathrm{p}=0.067\end{array}$ & $\begin{array}{c}11.00(10-13) \\
\mathrm{p}=0.440\end{array}$ \\
\hline \multirow{2}{*}{$\begin{array}{l}\text { Mesleği tekrar seçmek isteme } \\
\text { durumu }\end{array}$} & Evet & $64(52.5)$ & $15.00(13-16)$ & $12.00(10-14)$ \\
\hline & Hayır & $58(47.5)$ & $\begin{array}{c}14.00(12-16) \\
\mathbf{p}=\mathbf{0 . 0 4 4} *\end{array}$ & $\begin{array}{c}11.00(10-13) \\
\mathrm{p}=0.091\end{array}$ \\
\hline \multirow{2}{*}{$\begin{array}{l}\text { Mesleği bırakmayı isteme } \\
\text { durumu }\end{array}$} & Evet & $62(50.8)$ & $14.00(13-15)$ & $12.00(10-13)$ \\
\hline & Hayır & $60(49.2)$ & $\begin{array}{c}15.50(13-17) \\
\mathbf{p}=\mathbf{0 . 0 0 5} *\end{array}$ & $\begin{array}{c}12.00(10-14) \\
\mathrm{p}=0.235\end{array}$ \\
\hline \multirow{2}{*}{$\begin{array}{lll}\text { Çocuk oyunlarını bilme } \\
\text { durumu }\end{array}$} & Evet & $101(82.8)$ & $15.00(13-16)$ & $12.00(10-14)$ \\
\hline & Hayır & $21(17.2)$ & $\begin{array}{c}15.00(12-16) \\
\mathrm{p}=0.832\end{array}$ & $\begin{array}{c}12.00(10-14) \\
\mathrm{p}=0.806\end{array}$ \\
\hline \multirow{2}{*}{$\begin{array}{lll}\text { Çocuk } & \text { kitapları } & \text { okuma } \\
\text { durumu } & & \end{array}$} & Evet & $58(47.5)$ & $14.00(12-16)$ & $12.00(10-14)$ \\
\hline & Hayır & $64(52.5)$ & $\begin{array}{c}16.00(14-16) \\
\mathrm{p}=0.828\end{array}$ & $\begin{array}{c}11.00(10-13) \\
\mathrm{p}=0.712\end{array}$ \\
\hline \multirow{2}{*}{$\begin{array}{l}\text { Çocuk } \\
\text { durumu }\end{array}$} & Evet & 81 (66.4) & $14.00(12-16)$ & $12.00(10-14)$ \\
\hline & Hayır & 41 (33.6) & $\begin{array}{c}16.00(14-16) \\
\mathrm{p}=0.228\end{array}$ & $\begin{array}{c}11.00(10-13) \\
\mathrm{p}=0.927\end{array}$ \\
\hline \multirow{2}{*}{$\begin{array}{l}\text { Çocuk servisinde çalışmayı } \\
\text { isteme durumu }\end{array}$} & Evet & $46(37.7)$ & $14.00(12-16)$ & $12.00(10-14)$ \\
\hline & Hayır & $76(62.3)$ & $\begin{array}{c}15.00(13-16) \\
\mathrm{p}=0.077\end{array}$ & $\begin{array}{l}12.00(10-13) \\
p=0.733\end{array}$ \\
\hline
\end{tabular}




\section{Tartışma}

Klinik uygulama süreci öğrenci hemşireler ve diğer paydaşlar için karmaşık bileşenleri olan stresli bir süreç olmakla birlikte klinik yeterlilik, mesleki gelişim ve profesyonel kimlik kazanımı için kritik öneme sahiptir. Dolayısı ile geleceğin hemşireleri olan öğrencilerin klinik uygulama sürecinin verimliliği arttırılmalıdır. Bunun içinde konuya ilişkin sorunların belirlenmesinin önemli olacağ düşünülmekte olup, çalışmada pediatri hemşireliği öğrencilerinin klinik rahatlık ve endişe durumları değerlendirildi.

Çalışma grubu hemşirelik öğrencilerinin büyük çoğunluğunun mesleğini sevdiği, yarıdan fazlasının mesleği kendi isteği ile seçtiği, yarısının tekrar seçme olanağ belirlenmiştir. Hemşirelik öğrencilerine ilişkin çalışmalarda; öğrencilerin \%68.3'ünün hemşireliği isteyerek seçtiği ve \%80.5'inin hemşirelik mesleğini sevdiği (Ergin ve ark., 2018), \%89.2'sinin kendisini hemşirelik mesleğine ait hissettiği (Karagözoğlu ve ark., 2013), \%57.1'inin hemşire olmayı istediği (Yılmaz ve ark., 2017) saptanmıştır. Çalışmaların sonuçları bizim çalışma sonuçlarımızı desteklemektedir. Aynı zamanda sonuçlar hemşirelik mesleği adına oldukça sevindirici olup, bu oranların daha yüksek olması temennimizdir. Bireylerin mesleklerini isteyerek tercih etmeleri, sevmeleri mesleki başarı ve doyumu artırmakta, aksi durum ise olumsuz etkilere neden olabilmektedir.

Çalışmada hemşirelik öğrencilerinin büyük kısmının çocuk oyunlarını bildiği, yarısının çocuk kitapları okuduğu, yarısından fazlasının çocuk haklarını bildiği saptanmıştır. Hemşirelik öğrencilerin çocuk grubuna hizmet edebilmesi için onların dünyaları ile ilgili farkındalıkları sağlanmalıdır. Öğrencilerin yarıdan fazlası çalışma hayatında pediatri kliniğinde çalışmak istemediğini ifade etmiştir. Çalışmalarda, öğrencilerin hemşirelik eğitimi sürecinde en yoğun stres ve endişeyi pediatri kliniği uygulamalarında yaşadıkları belirlenmiştir. Pediatri kliniğinin spesifik özellikli olduğu, çocuklar ve burada karşılaşılan diğer kişilerle bağlantılı olarak karmaşık bir doğaya sahip olduğu bilinmektedir (Coetzee 2004; Chen 2010; Singh ve ark., 2011; Lassche ve ark., 2013; Altay ve ark., 2014). Karmaşıklığı çözmekte ise pediatri kliniğine özgü bilgi, tutum ve becerinin önemli olduğu ifade edilmektedir. Öğrenciler pediatri kliniğini korkutucu, zorlayıcı olarak algılamakta ve klinik olarak çalışma süreçlerinde tercih etmeyi düşünmemektedir.
Çalışmada hemşirelik öğrencilerin pediatri klinik uygulamasına ilişkin klinik rahatlık boyutu puanlarının orta düzeyde olduğu ve orta düzeyde klinik endişe yaşadıkları görüldü. Çunkuş ve arkadaşlarının (2019) çalışmasında pediatri dersi alan öğrencilerin klinik uygulamasına ilişkin Pediatri Hemşireliği Öğrencileri Klinik Rahatlık ve Endişe Değerlendirme Ölçeğinin Klinik Rahatlık alt boyutu puan ortalamas1 $16.13 \pm 2.36$, Klinik Endişe alt boyutlanı ise $13.40 \pm 3.11$ olarak saptanmış olup, çalışma sonucumuzu destekler niteliktedir. Bir yurt dışı çalışma örneğinde ise pediatri kliniği uygulamasında hemşirelik öğrencilerinin yüksek klinik endişe ve düşük klinik rahatlık yaşadıkları belirlenmiştir (Lassche ve ark., 2013). Literatürde klinik uygulamaların hemşirelik öğrencilerinin stres düzeylerine etkisinin incelendiği çalışmaların oldukça fazla olduğu görülmektedir. Yurt içi ve yurtdışı çalışma sonuçları incelendiğinde büyük çoğunluğunda hemşirelik öğrencilerinin klinik stres düzeyinin ortalamanın üstünde olduğu yani klinik stresin yoğun olduğu ifade edilmektedir (Chen 2010; Lassche ve ark., 2013; Altay ve ark., 2014; Khater ve ark., 2014; Kubin ve Wilson, 2017; Karaca ve ark., 2017; Ergin ve ark., 2018; Kılıç 2018). Pediatri kliniği uygulamasında öğrenciler oldukça geniş yelpazede yer alan farklı evrelerde büyüme gelişme özelliklerine sahip çocuklarla (yenidoğan, süt çocuğu, oyun çocuğu vs.) çalışmak ve klinik ortamdaki çevresel faktörlerle ilişkili olarak daha yoğun stres yaşamaktadır. Pediatri klinik uygulama öncesi öğrenci hemşirelere bu kliniğe ilişkin spesifik özelliklerin kazandırılması yönünde çalışmaların klinik rahatlığı artırabileceği, endişeyi ise azaltabileceği düşünülmektedir.

Çalışmada hemşirelik öğrencilerinin en çok rahatsızlık hissettikleri durumların çocuğa ilaç uygulamak ve ağrılı işlemler sırasında çocuklarınailelerinin baş etmelerine destek olma konusunda olduğu belirtilmiştir. Hemşirelik öğrencilerinin en büyük endişelerinin ise çocukta ağrıya sebep olma ve çocuğa fiziksel olarak zarar verme konusunda olduğu belirlenmiştir. Kalaycı ve arkadaşlarının (2019) çalışmasında öğrencilerin pediatri dersi klinik uygulamaya yönelik korkularına ilişkin ilk sırada "yanlış uygulama yaparak çocuğa zarar vermek" $(\% 67,8)$ yer almaktadır. Lassche ve arkadaşlarının (2013) çalışmasında ise pediatri kliniğinde hemşirelik öğrencilerin en büyük endişelerinin çocuklara yapılan işlemler sırasında ağrıya neden olmaktan kaynaklandığı saptanmıştır. Benzer bir çalışmada öğrenciler pediatri kliniğinde çoğunlukla çocuklara yanlış bir şey yapmaktan 
korktuklarını ve bilinmeyen durumlara ilişkin yoğun endişeler yaşadıklarını ifade etmiştir (Pulido Martos ve ark., 2011). Singh ve arkadaşları (2011) çalışmalarında intörn olan hemşirelik öğrencilerin pediatri kliniğinde yoğun stres yaşama nedenlerinin hasta grubu ve beceri eksikliğinden kaynaklandığını belirlemiştir. Oermann ve arkadaşları (2001) hemşirelik öğrencilerinin pediatri kliniğinde en yoğun stresi çocuğa yönelik ilaç uygulamalarına ilişkin yaşadıkları belirlemiştir. Aynı çalışmada yüksek stres düzeyinin klinik uygulamada korku ve hayal kırıklığı ile ilişkili olduğu, öğrencilerin klinik aktiviteleri ilişkin daha az uyarılmışlık ve uygulamaya daha az güven duyduğu belirlenmiştir (Oermann ve Lukomski, 2001). Literatürde hemşirelik öğrencilerinin pediatri kliniğinde yoğun endişe yaşama nedenlerinin; yenidoğan-bebekçocuğa dokunmak, çocuğa zarar vermek, çocukta ağrıya neden olmak, ilaç uygulamalarında hata yapmak, çocuk ve ebeveyn ile iletişim güçlüğü yaşamak, çocuk/ebeveyn tarafindan kabul edilmemek, çocuk ve aileye etkili bakım verememek, çocuk/ebeveyne psikososyal olarak yeterince destek olamamak, çocuk kliniğine ilişkin bilgi ve beceri eksikliği gibi düşüncelerden kaynaklandiğ1 görülmektedir (Oermann ve Lukomski, 2001; Coetzee 2004; Elçigil ve Yıldırım Sar1, 2011; Lassche ve ark., 2013; Arslan ve ark., 2018; Kalayc1 ve ark., 2019). Klinik uygulamalar öğrencilerin hemşirelik becerilerin kazanması için elzemdir, dolayısı ile bu sürecin optimum düzeyde faydalı geçmesi için gerekli önlemler alınmalıdır.

$\mathrm{Bu}$ çalışmada hemşirelik mesleğini seven öğrenciler, bugün seçme şansı olsaydı yine hemşirelik mesleğini seçecek olan ve hemşirelik mesleğini bırakmak istemeyen öğrenciler daha fazla rahatlık bildirmişlerdir. Ergin ve arkadaşları (2018) 3. sınıf hemşirelik öğrenci grubunun ağıllıklı olduğu bir çalışmada hemşirelik eğitimi stres ölçeği ve uygulama stresi alt boyutu puan ortalamaları ile öğrencilerin mesleği isteme ve sevme durumları arasında ilişki saptanmamıştır. Diğer taraftan bu çalışma sonucunu destekler nitelikte Karagözoğlu ve arkadaşlarının (2013) çalışmasında mesleki bilgi ve beceriyi yeterli düzeyde kazanmadığını düşünen ve kendini mesleğe ait hissetmeyen öğrencilerde klinik uygulama stresinin daha yüksek olduğu saptanmıştır. Başka bir çalışmada hemşire öğrencilerin istekliliğinin klinik uygulama ortamında pediatri hastalarının bakım bilgilerini kazanmada etkili olduğu ifade edilmektedir (Dafogianni ve ark., 2015). Glasper ve arkadaşları (2006) iyi bir çocuk hemşiresi olma arzu ve isteğinin çocuklarla çalışmakta önemli olduğunu vurgulamaktadır. Yılmaz ve arkadaşlarının (2017) çalışmasında da kendine güvenli, emin, pozitif, yapıcı ve sosyal destek arama yaklaşımı gibi tutumlarının hemşire olmayı isteyen öğrencilerin hemşire olmayı istemeyen öğrencilerden daha iyi olduğu bulunmuştur. Yani hemşirelik öğrencilerinin mesleklerine ilişkin olumlu düşüncelere sahip olma durumlarının mesleki bilgi, tutum ve becerilerini olumlu desteklediği görülmektedir.

\section{Sonuç}

$\mathrm{Bu}$ çalışma sonucunda pediatri kliniği hemşirelik öğrencilerinin klinik rahatlık ve klinik endişe durumlarının orta düzeyde olduğu belirlendi. Pediatri kliniğinde öğrencilerin en çok rahatsızlık hissettiği durum çocuğa ilaç uygulama ve ağrılı işlemler sırasında çocukların-ailelerin baş etmelerine destek olma, en çok endişe durumunun ise çocukta ağrıya sebep olma ve fiziksel zarar verme düşüncesinden kaynaklandığı görülmektedir. Hemşirelik öğrencilerinin mesleğini isteyerek seçme ve sevme durumları klinik rahatlığ etkilemektedir.

Hemşirelik öğrencilerinin mesleki bilgi ve becerileri geliştirilerek öz güvenlerinin artırılması klinik eğitim sürecinin etkinliği için oldukça önemlidir. Öğrenciler pediatri klinik eğitimi öncesi gereksinim ve koşullar dikkate alınarak modern eğitim yöntemleri ile (laboratuvar uygulamaları, simülasyon, video, senorya, vaka vb.) yenidoğan, bebek, çocuk ve ebeveynlerine ilişkin bakım, uygulama, iletișim konusunda desteklenmelidir. Ayrıca mesleki başarı için bireyler yapmak istedikleri, sevdikleri meslekleri seçmeleri konusunda yönlendirilmelidir.

\section{Araştırmanın Sınırlılıkları}

Araştırmanın, verilerin toplandığ 1 okul ve öğrenciler ile yapılmış olması bir sınırlılıktır. Bu yüzden, araştırmadan elde edilen sonuçlar, bu araştırma grubundaki hemşirelik bölümü öğrencilerine genellenebilir.

\section{Teșekkür}

Yazarlar çalışmaya katılan tüm öğrencilere teşekkür eder. 
Araștırmanın Etik Yönü/ Ethics Committee Approval: Araştırmanın yürütülmesi için ilgili üniversitenin Etik Komite Kurulu'ndan 2020/6 sayılı etik kurul onayı alınmıştır. Veri toplama aracı olarak kullanılan ölçeğin kullanımına ilișkin gerekli izin alınmıştır. Helsinki deklerasyonu ilkeleri kapsamında katılımcılar araştırmanın amacı, yöntemi hakkında yazılı olarak bilgilendirilmiş ve onamları alınmıştır.

Hakem/Peer-review: Dış hakem değerlendirmesi.

Yazar Katkısı/Author Contributions: Fikir/kavram: FÜT; Tasarım: FÜT; Danışmanlık: FÜT, NK; Veri toplama: FÜT; Veri işleme: FÜT, NK; Analiz ve/veya Yorum: FÜT, NK; Kaynak tarama: FÜT, NK; Makalenin Yazımı: FÜT, NK; Eleștirel inceleme: FÜT, NK.

Çıkar çatışması/Conflict of interest: Araştırmacılar arasında herhangi bir çıkar çatışması söz konusu değildir. Finansal Destek/Financial Disclosure: Çalışma için herhangi bir finansal destek alınmamıştır.

\section{Çalıșma Literatüre Ne Kattı?}

- Hemşirelik öğrencilerinin pediatri kliniği klinik rahatlık ve klinik endişe durumları orta düzeydedir.

- Pediatri kliniğinde öğrencilerin en çok rahatsızlık hissettiği durum çocuğa ilaç uygulama ve ağrılı işlemler sırasında çocukların-ailelerin baş etmelerine destek olmadır.

- Pediatri kliniğinde öğrencilerin en çok endişe durumu çocukta ağriya sebep olma ve fiziksel zarar verme düşüncesinden kaynaklanmaktadır.

- Hemşirelik öğrencilerinin mesleği isteyerek seçme sevme durumları klinik rahatlığı etkilemektedir.

\section{Kaynaklar}

Aedh AI, Elfaki NK, Mohamed IA. (2015). Factors associated with stress among nursing students (Najran University - Saudi Arabia). IOSR Journal of Nursing and Health Science, 4(6),33-38.

Altay N, K1lıçaslan Törüner F. (2014). Determining pediatric nursing students' clinical stres and liking of children scores. Dokuz Eylül Üniversitesi Hemşirelik Fakültesi Elektronik Dergisi, 7(3), 170-176.

Al-Qaaydeh S, Lassche M, Macintosh CI. (2012). Exploratory factor analysis of the Pediatric Nursing Student Clinical Comfort and Worry Assessment Tool. Journal of Pediatric Nursing, 27(5), 39-43.

Arslan S, Konuk Şener D, Cangür Ş. (2018). Pediatri hemşireliği öğrencileri klinik rahatlık ve endişe değerlendirme aracının geçerlik ve güvenirliği. Düzce Üniversitesi Sağlık Bilimleri Enstitüsü Dergisi, 8(2), 61-66.

Chan D. (2002). Development of the clinical learning environment inventory: using the theoretical framework of learning environment studies to assess nursing students' perceptions of the hospital as a learning environment. Journal of Nursing Education. 41(2), 69-75.

Chen J. (2010). Morale and role strain of undergraduate nursing students in a pediatric clinical setting. Journal of Nursing Research, 18(2), 144-53.

Cinar N, Altun I. (2012). 'Good pediatric nurse' characteristics in according to student nurses. HealthMed, 6(6), 1911-15.

Coetzee M. (2004). Learning to nurse children: Towards a model for nursing students. Journa of Advanced Nursing, 47(6), 639-48.

Çunkuş N, Solak S, Yiğitoğlu GT. (2019). Hemşirelik öğrencilerinin pediatri kliniği uygulamaları sırasında endişe ve rahatlık seviyeleri ile iletişim becerileri arasındaki ilișki. 18. Ulusal Hemșirelik Öğrencileri Kongresi Bildiri Kitab1. s.15. 25-27 Nisan 2019.

Dafogianni C, Alikari V, Galanis P, Gerali M, Margari N. (2015). Nursing students' views on their clinical placement in Pediatric Hospitals of Athens, Greece. International Journal of Caring Sciences. SeptemberDecember. 8(3), 673-682.

Egan T, Jaye C. (2009). Communities of clinical practice: the social organization of clinical learning. Health: An Interdisciplinary Journal for the Social Study of Health, Illness \& Medicine. 13, 107-125.

Elçigil A, Yıldırım Sarı H. (2011). Facilitating factors in clinical education in nursing. Dokuz Eylul University School of Nursing Electronic Journal, 4 (2), 67-71.

Ergin E, Çevik K, Çetin SP. (2018). Hemşirelik öğrencilerinin eğitimlerine ilişkin algıladığı stres ve stresle baş etme davranışlarının incelenmesi. Hemşirelikte Eğitim ve Araştırma Dergisi. 15(1), 16.

Facione PA, Crossetti MGO, Riegel F. (2017). Holistic critical thinking in the nursing diagnostic process. Revista Gaúcha Enfermagem, 38(3), e75576.

Glasper A, Richardson J, Whiting M. (2006). The highs and lows of learning to be a children's nurse. Paediatric Nursing, 18(6), 22-6.

Henderson A, Cooke M, Creedy, DK, Walker R. (2002). Nursing students' perceptions of learning in practice environments: A review. Nurse Education Today. 32, 299-330.

Jimenez C, Navia-Osorio PM, Diaz CV. (2010). Stress and health in novice and experienced nursing students. Journal of Advanced Nursing. 66(2), 442455.

Kalaycı S, Avc1 N, Azak M, Mutlu B. (2019). Pediatri dersi almış öğrencilerin klinik rahatlık ve endişe durumu ile öz yeterlilik algısı arasındaki ilişki. 18. Ulusal Hemşirelik Öğrencileri Kongresi Bildiri. s.276, 25-27 Nisan 2019.

Karaca A, Yıldırım N, Ankaralı H, Açıkgöz F, Akkuş D. (2017). Hemşirelik öğrencilerinin algılanan klinik stres düzeyi, stres cevapları ve baş etme davranışları. Psikiyatri Hemşireliği Dergisi. 8(1), 32-39. 
Karagözoğlu Ş. (2005). Bilimsel bir disiplin olarak hemşirelik. C.Ü. Hemşirelik Yüksek Okulu Dergisi. 9(1), 6-14.

Karagözoğlu Ş, Özden D, Tokyıldız F. (2013). Entegre program hemşirelik öğrencilerinin klinik stres düzeyi ve etkileyen faktörler. Anadolu Hemşirelik ve Sağlık Bilimleri Dergisi, 16(2), 89-95.

Khater WA, Akhu_Zaheya LM, Shaban IA. (2014). Sources of stress and coping behaviours in clinical practice among baccalaureate nursing students. International Journal of Humanities and Social Science, 4(6), 194-202.

Kılıç HF. (2018). Hemşirelik öğrencilerinin eğitim stresi ve mesleki benlik saygısı arasındaki ilişki, Hacettepe Üniversitesi Hemşirelik Fakültesi Dergisi, 5(1), 4959.

Kubin L, Wilson CE. (2017). Effects of community volunteer children on student pediatric assessment behaviors. Clinical Simulation in Nursing, 13(7), 303-308.

La Sala R, Ruozi C, Gavagni S, Martelli M, Marletta G, Primosa F. (2019). Nursing students' perception of the quality of clinical learning: a mixed methods inquiry. Acta Biomed for Health Professions, 90(6), 78-86.

Lassche M, Al-Qaaydeh S, Macintosh C, Black M. (2013). Identifying changes in comfort and worry among pediatric nursing students following clinical rotations. Journal of Pediatric Nursing, 28(1), 48-54.

Moghaddam HR, Aghamohammadi V, Jafari M, Absalan M, Nasiri K. (2020). Challenges faced by nursing students to work with nursing personnel: A
Qualitative Study. Advances in Medical Education and Practice, 22(11), 313-319.

Muslu L, Özsoy SA. (2017). Hemşirelik, estetik ve sanat. Hemşirelikte Eğitim ve Araştırma Dergisi, 14 (4), 287-291.

Oermann MH, Lukomski AP. (2001). Experiences of students in pediatric nursing clinical courses. Journal for Specialist in Pediatric Nursing, 6(2), 65-72.

Pulido Martos M, Augusto Landa JM, Lopez Zafra E. (2011). Sources of stress in nursing students: a systematic review of quantitative studies. International Nursing Review, 59, 15-25.

Randall D, Brook G, Stammers P. (2008). How to make good children's nurses: children's views. Paediatric Nursing, 20(5), 22-5.

Silva TP, Silva MM, Valadares GV, Silva IR, Leite JL. (2015). Nursing care management for children hospitalized with chronic conditions. Revista Brasialeria Enfermagem, 68(4),556-63. DOI: 10.1590/0034-7167.2015680410i.

Singh C, Sharma S, Kumar Sharma R. (2011). Level of stress and coping strategies used by nursing interns. Nursing and Midwifery Research Journal. 7(4),152160.

Theofanidis D, Fountouki A. (2006). Lifelong education in nursing science and practice. Nosileftiki (Hellenic Journal of Nursing). 45, 476- 482.

Yılmaz M, Yaman Z, Erdoğan S. (2017). Öğrenci hemșirelerde stres yaratan durumlar ve baș etme yöntemleri. Mersin Üniversitesi Sağl1k Bilim Dergisi. 10(2), 88-99. 